\title{
DISCHARGE PARAMETERS OF MAGNETOPLASMA COMPRESSOR: EFFECT OF EXTERNAL AXIAL MAGNETIC FIELD
}

\author{
D.G. Solyakov ${ }^{1,2}$, Yu.Ye. Volkova ${ }^{1,2}$, A.K. Marchenko ${ }^{1}$, M.S. Ladygina ${ }^{1}$, V.V. Staltsov ${ }^{1}$, \\ Yu.V. Petrov', V.V. Chebotarev ${ }^{1}$, T.M. Merenkova ${ }^{1}$, V.A. Makhlaj ${ }^{1,2}$, D.V. Yeliseyev ${ }^{1}$, \\ ${ }^{1}$ Institute of Plasma Physics NSC “Kharkov Institute of Physics and Technology", Kharkiv, Ukraine; \\ ${ }^{2}$ V.N. Karazin Kharkiv National University, Kharkiv, Ukraine
}

\section{E-mail: solyakov@ipp.kharkov.ua}

\begin{abstract}
This paper reports the findings of our recent experiments on the evaluation of the external axial magnetic field effect on the discharge parameters of a magnetoplasma compressor (MPC). The discharge-voltage characteristics were obtained for varied magnitudes of an external axial magnetic field produced by a solenoid installed on the accelerating channel. Present experiments were carried out with helium (at the initial pressures of 2 and 10 Torr) and argon (at the initial pressure of 1 Torr) as working gases at different initial voltages. The external magnetic field varied up to $0.4 \mathrm{~T}$. The discharge-voltage characteristics can be altered by the magnitude of the external magnetic field, as well as by the geometrical properties of an accelerating channel.
\end{abstract}

PACS: 52.40.Hf; 52.70

\section{INTRODUCTION}

High-current discharges that generate dense plasma flows have many applications in different areas of studies, including plasma-surface interaction and astrophysics. Quasistationary plasma accelerators (QSPAs) $[1,2]$ that are capable of generating powerful plasma streams now contain additional external magnetic field systems. It allows for studying the effect of an additional magnetic field on plasma flow parameters and simulating conditions close to those at the divertor plates of ITER under transient events [1-3]. A magnetoplasma compressor (MPC) is a quasistationary analog of plasma focus pinching discharge [4]. MPC generates dense plasma flows with pronounced compression zone - a specific region of plasma flow with maximum parameters of temperature and density, making it a source of plasma particles and EUV radiation needed for a number of applications [5-7]. Without an additional magnetic field, the MPC is able to generate plasma streams with energy density in the near-axis region of up to $50 \mathrm{~J} / \mathrm{cm}^{2}$ and total energy of $5.2 \mathrm{~kJ}[8]$.

In order to increase energy parameters further, we need to increase the discharge current. However, this can lead to a "current crisis" phenomenon characterized by a rapid rise of the discharge voltage when the discharge current reaches a certain critical value [9], making it impossible for greater currents to pass through. Not only the current crisis restricts the maximum achievable parameters but also damages the electrodes of the accelerator.

This effect can be partially diminished by making an external electrode (typically anode) transparent, thereby transferring to the mode of ion current transport in the accelerating channel. In this regime, which is realized in both QSPAs and MPCs, the discharge current is carried by ions coming from a transparent external electrode to a solid cathode. Further increase in the ions flow leads to an increase in a total mass flow rate, reducing the speed of a plasma flow. Thus, although the issue with the current crisis was partially resolved, even with this approach, the maximum discharge parameters are still limited as well as the problem with the erosion of the electrodes is not eliminated completely.

Another approach requires using an additional axial magnetic field. The results of numerical simulations revealed that in the presence of an axial magnetic field, the "current crisis" effect could be avoided [10]; nonetheless, further research by the same author shows that density and temperature noticeably decrease in the compression zone when an additional axial magnetic field is applied [11]. In the experiments on the MPC of compact geometry [12] with the externally imposed magnetic field, the following numerical estimations have shown that higher temperatures in the compression region can be achieved by increasing the magnitude of an axial magnetic field.

In the very first experimental studies with the MPC operating in the externally imposed axial magnetic field, we paid particular attention to the measurements of the electric field radial component, the discharge current, and the potential difference [13]. We found that the voltage between the MPC electrodes, as well as the part of the discharge current flowing outside the MPC channel, increases with the increase in the axial magnetic field magnitude. This result is compatible with the numerical simulations performed in [10].

However, the integral characteristics of the MPC discharge in the additional magnetic field have not been studied experimentally yet. Thus, it is still unknown whether imposing an axial magnetic field affects the discharge parameters.

In this paper, we report our recent experimental results of the measurements of the discharge-voltage curves (current-voltage curves), which are an essential characteristic of a discharge that shows how the discharge voltage changes with the discharge current. The experiments were performed for varying values of an external axial magnetic field carried out for two working gases at different initial pressures.

This paper is structured in the following order: the first section describes the experimental setup and ISSN 1562-6016. BAHT. 2018. №6(130) 
diagnostics equipment, followed by the second section devoted to the main experimental findings. The last section summarizes the outcomes.

\section{EXPERIMENTAL DEVICE AND DIAGNOSTICS}

The accelerating channel of the MPC used in the present experiments $[14,15]$ consists of two coaxial copper electrodes. An external electrode (anode) is formed by a solid cylindrical part and a conical part consisting of 12 rods inclined at 7.5 degrees to the axis of the channel. The cylindrical part is $12 \mathrm{~cm}$ in diameter and $14.5 \mathrm{~cm}$ in length. Each rod of the conical part of the anode is $14.7 \mathrm{~cm}$ in length and $1 \mathrm{~cm}$ in diameter. Following a similar shape, an internal electrode (cathode) consists of both cylindrical and conical parts as well. A solid cylinder-like part of the cathode is $20.8 \mathrm{~cm}$ in length and $6 \mathrm{~cm}$ in diameter, while a $12 \mathrm{~cm}$ long conical part with an outlet diameter of $3 \mathrm{~cm}$ has a hollow at its end acting as a divertor for impurities coming from the main plasma flow.

A system of capacitor banks triggered by a vacuum spark gap supplies the MPC discharge. The total capacitance of the capacitors system is $90 \mu \mathrm{F}$, with a maximum voltage reaching up to $30 \mathrm{kV}$. The MPC system of the electrodes is placed inside a solenoid that produces an axial magnetic field in the accelerating channel. The inner diameter and the total length of the solenoid are 15 and $17 \mathrm{~cm}$, respectively. Fig. 1 shows a general view of the entire system involving the solenoid with the MPC accelerating channel inside.

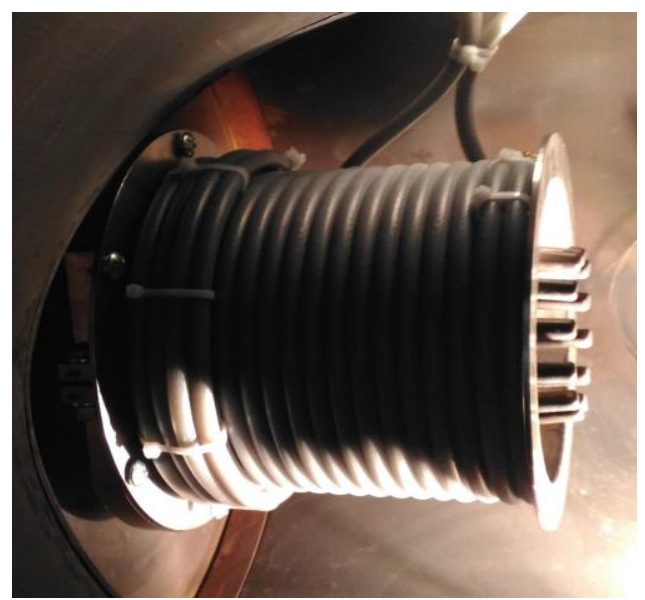

Fig. 1. MPC with a solenoid

The solenoid can generate an axial magnetic field with the maximum magnitudes in the range of 0.05 and $0.4 \mathrm{~T}$ inside the MPC channel. Fig. 2 [13] illustrates the axial distribution of the axial magnetic field $B_{z}$ in the accelerating channel. A capacitor bank with a total capacitance of $700 \mu \mathrm{F}$ supplies the solenoid. The complete system of the MPC with the solenoid is installed in the $40 \mathrm{~cm}$-wide vacuum chamber of $2 \mathrm{~m}$ in length.

The MPC device operates in the regime with residual gas at different pressures in the vacuum chamber. In our experiments, we used helium ( 2 and 10 Torr) and argon (1 Torr) as working gases for plasma creation during the discharge.
In order to measure the current-voltage curves, we varied the input voltage from the supplying system in the range of 10 and $20 \mathrm{kV}$.

We used the Rogowski coil and high-voltage dividers to measure the total discharge current and voltage, correspondingly.

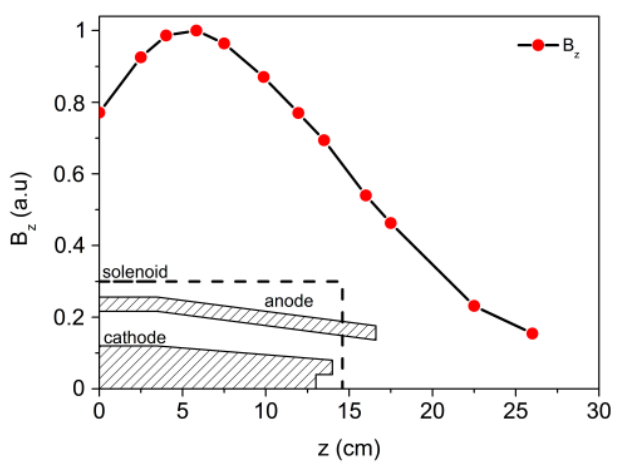

Fig. 2. Distribution of axial magnetic field $B_{z}$ along the axis $z$ inside the accelerating channel obtained at a capacitor's voltage of $1 \mathrm{kV}$

\section{EXPERIMENTAL RESULTS}

We conducted a set of experiments dedicated to the evaluation of the external magnetic field effect on the discharge-voltage (current-voltage) curves of the MPC discharges on different gases at varying pressures. Fig. 3 presents the typical waveforms of the discharge current and voltage measured during the discharge on helium ( 2 Torr) with the externally imposed magnetic field of $0.26 \mathrm{~T}$. Oscillations of the discharge current have at least three half-periods. The first half-period of the discharge current is approximately $8 \ldots 10 \mu \mathrm{s}$, while the discharge duration reaches as high as $30 \mu$ s. Up to the moment of the first half-period, the discharge is already stable and has reached its typical parameters.

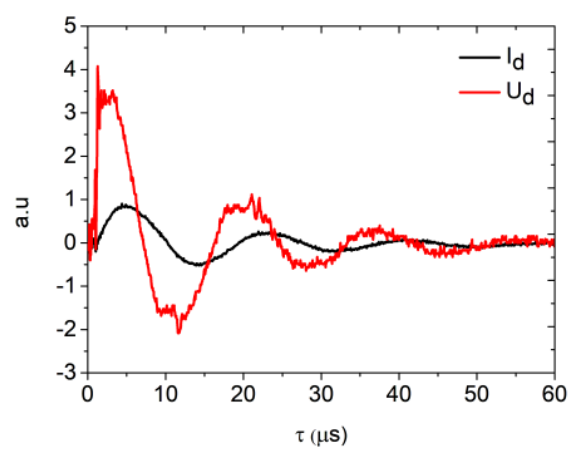

Fig. 3. Typical waveforms of the discharge current $I_{d}$ and discharge voltage for helium at 2 Torr, external magnetic field of $0.26 \mathrm{~T}$, and input voltage of $20 \mathrm{kV}$

Current-voltage curves showing the relation between the discharge current and the discharge voltage between the electrodes were obtained for the discharges in helium (Fig. 4) and argon (Fig. 5). For the following plots, we selected the maximum values of the discharge current and corresponding discharge voltage reached at approximately $5 \mu \mathrm{s}$ of the discharge. In the case of helium at the initial pressure of 2 Torr (see Fig. 4, a), higher discharge voltages were obtained when no 
external magnetic field was applied (the solenoid was switched off). With the external magnetic field of $0.4 \mathrm{~T}$, the highest value of the discharge voltage (at $20 \mathrm{kV}$ of input voltage) drops roughly $11 \%$ of that with no magnetic field imposed. The external magnetic field of $0.13 \mathrm{~T}$ corresponds to the highest discharge current of $362 \mathrm{kA}$.

Conversely, with a higher initial pressure of helium (see Fig. 4,b) and, therefore, a higher mass flow rate, the discharge voltage increases when the external magnetic field of $0.4 \mathrm{~T}$ is imposed. However, it is still lower than in the previous case because the discharge voltage is inversely proportional to a mass flow rate [9]. It is worth noting that compared to the old curve obtained before the installation of the solenoid, the discharge voltage rises with the increasing external magnetic field except for the case with $0.13 \mathrm{~T}$. This possibly indicates that the discharge voltage does not depend linearly on the magnitude of an external magnetic field, as opposed to what had been obtained before.

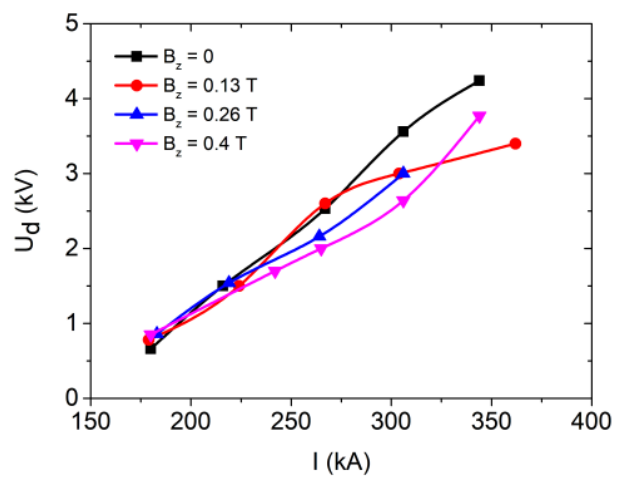

a

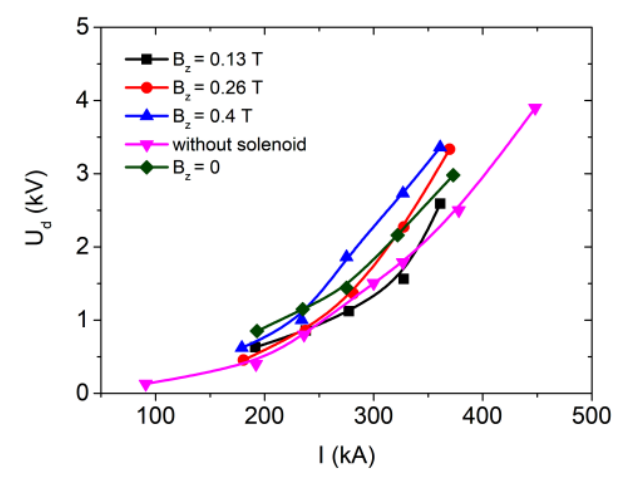

b

Fig. 4. Comparison of the current-voltage curves obtained for He (2 Torr) (a) and He (10 Torr) (b). The latter includes the current-voltage curve obtained during past experiments before the solenoid was installed

Moreover, the current-voltage curve with no magnetic field does not utterly coincide with the old result. This difference must have resulted from the change of the geometrical parameters of the channel caused by the cylindrically shaped solenoid installed on it. Such an effect of the solenoid channel should be taken into consideration.

The current-voltage curves for argon with the initial pressure of 1 Torr (see Fig. 5) demonstrate a similar pattern as those of the latter case: the most pronounced difference in the discharge voltage value is observed between the old curve and the curve obtained with no field.

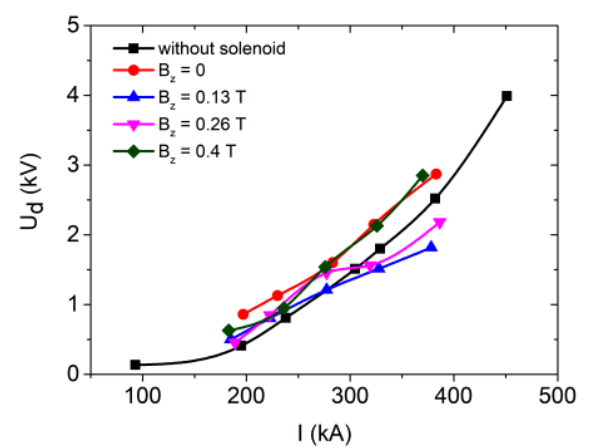

Fig. 5. Comparison of the current-voltage curves obtained for Ar (1 Torr) at varied external magnetic field and the curve obtained during past experiments before the solenoid was installed

Fig. 6 compares the instantaneous electric power of the discharge of two regimes of operation with the same mass flow rate: argon (1 Torr) and helium (2 Torr) at $20 \mathrm{kV}$ of input voltage. As it follows from the plots above (see Fig. 4,b, and Fig. 5), when the mass flow rate is the same, the highest value of the discharge voltage reaches approximately $3.36 \mathrm{kV}$ when $0.4 \mathrm{~T}$ of the external magnetic field is applied to the discharge in helium at the initial pressure of 10 Torr. This corresponds to the instantaneous discharge power of about $1200 \mathrm{MW}$.

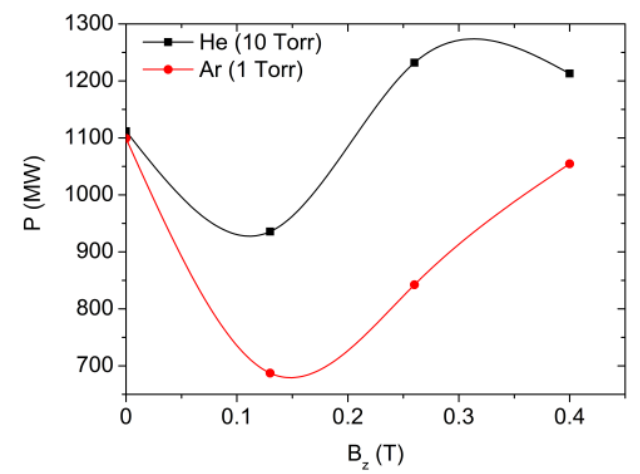

Fig. 6. Instantaneous discharge power for Ar (1 Torr) and He (10 Torr) at $20 \mathrm{kV}$ of input voltage

\section{CONCLUSIONS}

A possible effect of an external axial magnetic field on the current-voltage curves of the MPC discharge has been studied experimentally. The discharge current, and the voltage between the MPC electrodes, were measured for different magnitudes of the external axial magnetic field and working gases by changing the value of the input voltage. Our findings demonstrate that the currentvoltage curves of the MPC can be altered by the magnitude of the external magnetic field. The effect caused by the change in the geometrical properties of a channel should also be taken into account in further research. Therefore, future investigation of the MPC discharge behavior in the presence of an external axial magnetic field is of extreme importance. 


\section{ACKNOWLEDGEMENTS}

This work has been supported by the Targeted Program of National Academy of Sciences of Ukraine (NASU) on Plasma Physics № П- 9/24-2020.

\section{REFERENCES}

1. I.E. Garkusha et al. Influence of a magnetic field on plasma energy transfer to material surfaces in edgelocalized mode simulation experiments with QSPA-M // Nuclear fusion. 2019, v. 89, № 8, p. 086023.

2. A.A. Shoshin, A.V. Arzhannikov, et al. Plasmasurface interaction during ITER type I ELMs: comparison of simulation with QSPA Kh-50 and the GOL-3 facilities // Fusion Science and Technology. 2011, v. 59 (1T), p. 57-60.

3. I.E. Garkusha, V.A. Makhlai, et al. Tungsten melt losses under QSPA Kh-50 plasma exposures simulating ITER ELMS and disruptions // Fusion Science and Technology. 2014, v. 65(2), p. 186-193.

4. R. Kwiatkowski, E. Skladnik-Sadowska, et al. Measurements of electron and ion beams emitted from the PF-1000 device in the upstream and downstream direction // Nukleonika. 2011, v. 56(2), p. 119-123 (in Russian).

5. L.Ya. Min'ko, V.M. Astashinskii, A.A. Man'kovskii. Compression of erosion plasma fluxes of given composition in air at atmospheric pressure (letters to the editor) // Journal of Applied Spectroscopy. 1991, v. 55(6), p. 1191-1193.

6. V.M. Astashynski et al. Choice of operating conditions and plasma parameters of a magnetoplasma compressor // Journal of Engineering Physics. 1992, v. 62(3), p. 386-390.

7. I.E. Garkusha et al. EUV radiation from pinching discharges of magnetoplasma compressor type and its dependence on the dynamics of compression zone formation // Physica Scripta. 2014, T161, p. 014037.

8. V.M. Astashynski, S.I. Ananin, V.V. Chebotarev, et al. Energy characteristics of plasma streams, generated by MPC // Problems of Atomic Science and Technology. Series «Plasma Physics». 2013, № 1(83), p. 122-124

9. A.I. Morozov. Introduction to Plasmadynamics. Moscow: "Fizmatlit", 2006.

10. A.N. Kozlov. Basis of the quasi-steady plasma accelerator theory in the presence of a longitudinal magnetic field // J. Plasma Physics. 2007, v. 74, part 2, p. 1-26.

11. A.N. Kozlov. Study of MHD dynamo effect at the outlet from plasma accelerator in the presence of longitudinal magnetic field // Contrib. Plasma Phys. 2020, p. e201900174.

12. A.Z. Giovannini, I. Barendregt, et al. Self-confined plasma in a magneto-plasma compressor and the influence of an externally imposed magnetic field // Plasma Sources Sci. Technol. 2015, v. 24, № 2, p. 025007.

13. D.G. Solyakov, Y.E. Volkova, et al. Discharge characteristics in the MPC channel in presence of external longitudinal magnetic field // Problems of Atomic Science and Technology. Series «Plasma Physics». 2019, №1, p. 208-211

14. T.N. Cherednychenko et al. Local magnetohydrodynamic characteristics of the plasma stream generated by MPC // Acta Polytechnica. 2013, v. 53(2), p. 131-133.

15. T.N. Cherednychenko et al. Creation of a compression zone in the plasma steam MPC under different initial conditions // Ukrainian Journal of Physics. 2017, v. 62(4), p. 306-310.

Article received 10.11.2020

\section{ПАРАМЕТРЫ РАЗРЯДА МАГНИТОПЛАЗМЕННОГО КОМПРЕССОРА: ВЛИЯНИЕ ВНЕШНЕГО ПРОДОЛЬНОГО МАГНИТНОГО ПОЛЯ}

\section{Д.Г. Соляков, Ю.Е. Волкова, А.К. Марченко, М.С. Ладыгина, В.В. Стальцов, Ю.В. Петров, В.В. Чеботарёв, Т.Н. Меренкова, В.А. Махлай, Д.В. Елисеев}

Представлены результаты экспериментов по изучению влияния внешнего продольного магнитного поля на параметры разряда магнитоплазменного компрессора (МПК). Вольт-амперные характеристики были получены для разных значений внешнего продольного магнитного поля, которое создаётся соленоидом, установленным на ускорительный канал МПК. Эксперименты проводились с использованием гелия (при начальном давлении от 2 до 10 Торр) и аргона (при начальном давлении 1 Торр) в качестве рабочих газов при разных начальных напряжениях. Внешнее магнитное поле менялось до 0,4 Тл. Вольт-амперные характеристики могут меняться в зависимости от величины внешнего продольного магнитного поля, а также от геометрических параметров ускорительного канала.

\section{ПАРАМЕТРИ РОЗРЯДУ МАГНІТОПЛАЗМОВОГО КОМПРЕСОРА: ВПЛИВ ЗОВНІШНЬОГО ПОЗДОВЖНЬОГО МАГНІТНОГО ПОЛЯ}

\section{Д.Г. Соляков, Ю.С. Волкова, А.К. Марченко, М.С. Ладигіна, В.В. Стальцов, Ю.В. Петров, В.В. Чеботарьов, Т.М. Меренкова, В.О. Махлай, Д.В. Слісєєв}

Наведено результати експериментів з вивчення впливу зовнішнього поздовжнього магнітного поля на параметри розряду магнітоплазмового компресора (МПК). Вольт-амперні характеристики було отримано для різних значень зовнішнього поздовжнього магнітного поля, що створюється соленоїдом, який встановлено на прискорювальному каналі МПК. Експерименти було проведено з використанням гелію (за початкового тиску від 2 до 10 Торр) та аргону (за початкового тиску 1 Торр) у якості робочих газів за різних значень початкової напруги. Зовнішне магнітне поле змінювалося до 0,4 Тл. Вольт-амперні характеристики можуть змінюватися залежно від величини зовнішнього поздовжнього магнітного поля, а також від геометричних параметрів прискорювального каналу. 